\title{
Environmental SLAPPs in the UK: threat or opportunity?
}

Article

Accepted Version

Hilson, C. (2016) Environmental SLAPPs in the UK: threat or opportunity? Environmental Politics, 25 (2). pp. 248-267. ISSN 1743-8934 doi:

https://doi.org/10.1080/09644016.2015.1105176 Available at https://centaur.reading.ac.uk/44535/

It is advisable to refer to the publisher's version if you intend to cite from the work. See Guidance on citing.

Published version at: http://dx.doi.org/10.1080/09644016.2015.1105176

To link to this article DOI: http://dx.doi.org/10.1080/09644016.2015.1105176

Publisher: Taylor and Francis

All outputs in CentAUR are protected by Intellectual Property Rights law, including copyright law. Copyright and IPR is retained by the creators or other copyright holders. Terms and conditions for use of this material are defined in the End User Agreement.

\section{www.reading.ac.uk/centaur}

\section{CentAUR}

Central Archive at the University of Reading

Reading's research outputs online 


\title{
Environmental SLAPPs in the UK: Threat or Opportunity?
}

Christopher J. Hilson, School of Law, University of Reading, UK

Email: Christopher J. Hilson [c.j.hilson@reading.ac.uk]

\begin{abstract}
Strategic lawsuits against public participation (SLAPPs) brought against the environmental movement in the UK since the 1990s are examined. SLAPPs, a form of Green backlash, have been mobilised across a wide range of policy areas that have seen vigorous campaigning and protest by the movement, including roads, GMOs and, more recently, climate change. SLAPPs are typically regarded as a threat, designed to close down democratic free speech and protest. However, in the UK, there are some notable cases where the environmental movement has been able to use agency to convert what may appear as a legal threat into a positive legal or media opportunity.
\end{abstract}

\section{Key Words}

SLAPPs, legal mobilisation, environmental movement, legal opportunity structure, protest

\section{Introduction}

The acronym 'SLAPP' stands for a strategic lawsuit (or litigation) against public participation and was coined in the US in the 1980s (Pring and Canan 1996). Its American origins should come as no surprise: just as the US was the site for significant litigation brought by the environmental movement (Morag-Levine 2003, Vanhala 2012), it also turned out to be one for strategic litigation against the movement as a form of 'Green backlash' (Rowell 1996). In a study of SLAPPs in Canada, Sheldrick (2014) argues that such lawsuits have received much more attention in the US than in Canada in part because of the greater litigiousness of American political culture and partly also because the practice and study of public interest law is much better established there. While such causal claims clearly require further scrutiny, SLAPPs in the UK have received relatively little academic attention. Donson's $(2000,2010)$ work is a rare exception. ${ }^{1}$

The principal research question explored here is: why do members of the environmental movement choose to fight SLAPPs as a strategic option? If there is a weakness with the existing SLAPPs literature it is that it tends to be rather under-theorised: many of the studies provide numerous practical examples of SLAPP cases and will often discuss them in the context of constitutional rights protections, but few make 
an attempt to think about SLAPPs in a theoretical context. My aim is to answer the research question by examining UK environmental SLAPPs using theories from the socio-legal literature on legal mobilisation, including legal opportunity structure and resource mobilisation.

My focus is very much on how the environmental movement responds to SLAPPs. I begin by defining SLAPPs and analysing their role in the so-called 'judicialisation of politics' before using theoretical concepts such as legal opportunity to examine why and where the movement has been able to respond strategically to them. This theoretical argument is then supported by an empirical examination of UK SLAPPS involving the environmental movement since the 1990s. The existing literature tends to portray SLAPPs as threats to social movement actors, producing a chilling effect on democratic free speech and protest (Beder 1995, Wells 1998; cf. Sheldrick 2014). However, there are some high profile UK cases where the environmental movement has been able to convert the legal threat posed by SLAPPs into a positive legal or other form of opportunity. I argue that agency on the part of the movement is largely key to explaining this transformative effect, although structural elements such as legal opportunity also play a part.

\section{What is a SLAPP?}

Pring and Canan (1996) define a SLAPP as a civil claim brought against non-governmental individuals or organisations on an issue of public interest, objecting to their communications made to influence a governmental action or outcome. This definition sits within a particular US context involving the constitutional right to petition government, with Pring and Canan concerned about lawsuits which seek to interfere with this right. However, their definition has been criticised for its narrowness (Sheldrick 2014): after all, campaigning and protest activity directed at private companies is also political expression worthy of protection from SLAPP suits designed to silence it. For present purposes, a SLAPP covers civil claims brought in relation to environmental campaigning or protest action which threaten the right of those challenged to bring matters of public interest to wider attention and/or which go beyond what is necessary to protect the claimant's private rights. As will be seen below, SLAPPs can be brought by the state as well as private companies. However, in line with most of the existing literature (cf. Gleason 2003), I do not include criminal prosecutions brought by the state against social movement actors, although these too are of course capable of having a chilling effect on activist behaviour.

\section{SLAPPs and the Judicialisation of Politics}


Sheldrick rightly draws attention to the important relationship between SLAPPs and the so-called judicialisation of politics (and the associated politicisation of the courts). This involves the idea that politics has been displaced from democratic legislative fora to the courts, particularly as a result of a turn to rightsbased judicial review. The phenomenon has arguably been most striking where constitutional rights instruments are relatively new, such as in the case of the Charter of Rights and Freedoms in Canada or the Human Rights Act in the UK. While supported by many, as Sheldrick observes, the turn to the courts by social movement actors has also been the subject of criticism from both the Left and the Right. The former have either pointed towards a tendency for law to neutralise politics through translation into technical legal language, thereby acting as a demobilising force (Hutchinson and Petter 1988, Sheldrick 2014), or have portrayed law as a dead end or 'hollow hope', incapable of securing desired social change (Rosenberg 2008). Some on the Right, in contrast, have decried the displacement of politics from democratic political institutions to undemocratic courts (Morton and Knopff 2000, Sheldrick 2014), principally because of the mobilisation of rights by Left-liberal causes.

However, the study of SLAPPs is important because such lawsuits demonstrate that political use of the courts is not confined to constitutional judicial review claims in the highest courts. As Sheldrick (2014: 4) states:

A consideration of SLAPPs has much to tell us about the relationship between law and politics, and about the broader question of the role courts play in our political system. In particular, it offers a corrective to ... an overemphasis on "constitutionalism" as the primary context in which the relationship between law and politics takes place. While it is understandable that one should pay attention to the decisions of the Supreme Court of Canada, at the same time the relationship between law and politics plays out in a number of other judicial and quasi-judicial contexts.

SLAPPs also illustrate that attempts to shift matters from the political to the legal realm are not confined to social movement actors (Sheldrick 2014). Typically, the whole point of a SLAPP suit is to convert a matter of public interest into a technical private law dispute, robbing it of political framing and providing a legal one instead (Pring and Canan 1996, Donson ,2000, 2010). If some Left-leaning critics feared that the use of public law judicial review proceedings would be demobilising, then a turn towards private law is potentially worse still, because private law is very much about the resolution of disputes between individuals (as opposed to public law with its aim of holding public authorities to account, which inevitably lends a political quality to proceedings). As Beder (1995: 25) has observed, 'Another effect of the SLAPP is to distract the key antagonists from the main controversy and use up their money, time and energy in the courtroom, where the issues are not discussed'. However, the intersection between law and politics does 
not stop there, because, as will be seen below, SLAPPs may offer defendant social movement actors the opportunity to raise political defences. Such defences have the capacity to re-inscribe the public and the political within what is otherwise an individualised private law dispute. This means that Beder's demobilising blind alley may not always materialise: such defences, where available, ensure that 'the issues' will continue to be discussed.

In terms of the interplay between law and politics, there are thus three key elements to SLAPPs. First, political campaigning and protest may be alleged to have interfered with someone else's private legal rights (to their property, reputation, etc). The courts are, inevitably, involved in trying to secure a balance between the conflicting rights at play: the right to free political expression of the SLAPP defendants versus the private rights of the claimants. Second, litigation brought to uphold those private rights may be politically motivated - really aimed at closing down political expression rather than protecting private rights. It is for this reason that the term 'strategic' is found in the SLAPPs acronym, suggestive as it is of a different real motive to the apparent one. And finally, as described in the paragraph above, there is scope for the use of political defences by social movements to prevent the tendency induced by SLAPPs to convert political public interest issues into merely technical private law disputes. Such defences may have the effect of re-politicising the otherwise de-politicised legal space of private law.

It is this final element that is my focus here. Given that the SLAPPS cases examined below involve the environment, a key contribution I seek to make to environmental politics is to argue that it is not only environmental judicial review claims brought by the environmental movement that are a site for the judicialisation of environmental politics; civil suits (and, though not the focus here, criminal prosecutions) brought against the movement also involve the opportunity, through the strategic use of defences, for environmental politics to be played out in a court setting.

\section{SLAPPs, Legal Opportunity Structure and Resource Mobilisation}

Legal opportunity structure (LOS) has become a key theoretical concept used to help explain why social movements choose litigation as a strategy (Hilson 2002, Andersen 2005, Wilson and Rodríguez-Cordero 2006, Vanhala 2011, 2012). Central to LOS is the idea of access to the courts. As Vanhala (2011) notes, access routes may be varied. The greatest scholarly focus tends to be on social movement access as a claimant via 'proactive' litigation (Harlow and Rawlings 1992, Vanhala 2011), with judicial review being the typical procedure studied. However, as Vanhala observes, the danger is that such a focus underplays the important role played by other means of social movement access to courts, including intervention as third 
parties (e.g. via amicus briefs) and, more significantly for present purposes, via 'reactive' litigation where social movements actors are themselves taken to court as defendants (Harlow and Rawlings 1992, Vanhala 2011). More recent literature has taken heed of this warning, urging scholars to pay more attention to the latter (Hilson 2012, Doherty and Hayes 2013). However, while it has since explored reactive litigation in more depth, this has typically been limited to criminal prosecutions (cf. Finchett-Maddock 2013). A common situation here is that social movement activists deliberately seek arrest and prosecution during protests and then use their 'day in court' to make political arguments in defence of their allegedly unlawful behaviour. Thus Hilson (2012), for example, has examined how reactive litigation of this type has formed a significant sub-category of climate change litigation in the UK. Doherty and Hayes (2013) have explored the way in which French and English GMO crop-trashers have responded to prosecution and the judicial opportunities offered by the respective countries. The current study seeks to add to this literature by analysing SLAPPs as a type of reactive civil rather than criminal litigation.

It is worth further exploring the application of legal opportunity theory to reactive litigation at this point. The first thing to note is context. In the paragraph above we saw that legal opportunity structure has typically been used as an independent variable to help explain the choice of litigation as a strategy, as the dependent variable. Thus, one might, for example, expect low levels of litigation where aspects of the legal opportunity structure (such as restrictive standing rules) are poor. Nevertheless, with reactive litigation, it is less obvious that social movement actors are 'choosing' strategic litigation: on the surface at least, it seems to be choosing them. However, Vanhala (2011) usefully distinguishes between 'active' and 'passive' reactive litigation, with the latter applying where the litigation is not purposefully instigated, welcomed or, failing that, acknowledged as a strategic opportunity by the defendant. With active reactive litigation, defendants do actively choose. That said, there is a difference between criminal and civil reactive litigation in terms of what they choose. In criminal cases, as we saw in the previous paragraph, social movement actors will often make two deliberate choices: first to take action which invites arrest and prosecution; and second to defend prosecution in court by using political defences where available. In civil cases in contrast, there are few if any examples of social movement actors deliberately courting civil proceedings. So there is just one level of choice there: if proceedings come, then active reactive litigation involves movement actors strategically choosing to defend them, again using political defences where available. The point is that, at first sight, LOS explanations may not look at all relevant in the context of reactive litigation. However, on closer inspection, such explanations remain applicable because, like proactive litigation, reactive litigation still involves the issue of social movements choosing to use litigation strategically. Nevertheless, the next paragraph will explore how far the details of LOS, developed in the literature for proactive litigation, actually make sense for reactive litigation, and where potential differences apply. 
Legal opportunity approaches tend to include issues of access to courts mentioned above, but also 'legal stock' (Andersen 2005) which involves finding a suitable legal rule or principle on which to base a case, and judicial receptivity (Hilson 2002), which is a matter of how judges in particular cases react to those legal arguments (and thus, ultimately, whether the outcome of the case is successful or not in a direct sense). With access, 'Questions of standing ... and other procedural hurdles (often included in LOS approaches) become moot when the activist is a defendant and is obligated to appear in court' (Vanhala 2011: 23). In reactive cases, in other words, one typically cannot argue that the access aspect of LOS has a bearing on the use of strategic litigation, because defendants will generally have guaranteed access. Nevertheless, the emphasis on 'typically' and 'generally' is important. As will be seen later when examining the UK cases, some interim injunctions are granted ex parte (i.e. with only the claimant present) and without notice. In such cases, because of civil procedure rules that allow the defendant to be excluded, a lack of access to court rules out opportunities for raising an immediate defence. While defendants are entitled to mount later challenges, this may come at significant financial cost to them, and thus such challenges will be all but impossible for those without significant means or external financial support. This issue of resources will be discussed further below.

Perhaps more than access, the legal stock element of legal opportunity is especially relevant. As will be seen from the UK cases below, not every SLAPP suit offers defendants suitable defences that they can politicise: in some, only a very technical defence can be marshalled. That fact may deter social movement actors from deciding strategically to fight the case. Judicial receptivity is also still applicable: very few SLAPP suits result in success for defendants in court, but equally, technical legal success to vindicate private rights is generally not the real aim of SLAPP claimants even if they do typically win; the true purpose is, rather, to silence protest and political debate. Furthermore, claimants are often able to achieve this purpose without actually taking a case right through to a 'winning' judgment: cases are frequently dropped without securing a paper vindication of the relevant private rights, because the real aim (and thus also a ' $w i n$ ') has been achieved merely by launching legal proceedings or even by only threatening to launch them. In such instances, it is not easy to gauge what judicial receptivity would have been had the case progressed to judgment. However, in any event, just as Vanhala's (2012) work on strategic proactive litigation by the UK environmental movement shows that poor legal opportunity, including judicial receptivity, was not a barrier to the movement adopting a vigorous litigation strategy, so too with reactive litigation, one should not conclude that poor judicial receptivity will necessarily preclude movement actors 
from making a strategic choice to fight SLAPPs. After all, there are still wins to be had beyond the official court room door, in particular in the court of public opinion: political defences provide a means of getting a policy message across, and, in the case of individual defendants up against large multinational corporations, the David versus Goliath nature of the proceedings may play into the defendants' hands.

Reactive litigation can also be discussed within alternative theoretical explanations for the use of litigation as a strategy such as resource mobilisation. While much of the literature suggests that, because of the significant expense associated with litigation, it is only financially well-off groups that can afford access to the courts, Vanhala (2011) states that this is only really true of proactive litigation. Reactive litigation, in contrast, is financially relatively costless and hence resource mobilisation theory is, she claims, unable to account for the strategic use of, for example, the criminal prosecution type case by social movement actors.

However, resources are important in relation to protest-based civil litigation in two respects. As will be seen from the UK cases below, first, financially well-off individuals and groups may be put off further protest after having injunctions or damages claims served on them or being threatened with them. Injunctions or being sued for damages, in other words, may have a chilling effect on protest for the resource rich. The archetypal young and poor eco-warrior, in contrast, is unlikely to be put off as they have little or nothing to lose financially. Second, and contrary to Vanhala's view, resources do seem to be important for explaining the uptake of civil reactive litigation in some cases. Few individuals are entitled to civil legal aid (and in some instances, such as defamation, it was historically unavailable to anyone). For those who do not receive such state support, the ability to challenge, for example, an injunction will often be ruled out on financial grounds: for most middle class protestors, the legal expenses involved and the possibility of having to pay the other side's costs are likely to rule it out.

Finally, one of the potential problems with purely structural legal opportunity explanations is that they miss the possibility for agency on the part of social movement actors (Vanhala 2011). Such agency involves the capacity to perceive what on the surface may appear to be legal threats posed by reactive litigation, including SLAPPs, and to shape them into legal or other types of opportunities. Or, to put it in different terms, agency may turn negative legal opportunities into positive opportunities, legal or otherwise. However, in the context of court-based responses, such agency is likely to interact with the other variables above such as resources and LOS. Thus, with the former, those most likely to be in a position to exert agency in court will be precisely those who are either financially supported in some way or who are not fazed by the financial implications of SLAPP lawsuits. Legal stock also remains important: try all one might 
in terms of agency, only with certain types of reactive litigation will there be scope for the deployment of creative defences.

\section{UK SLAPPs}

My aim in this section is not to present an exhaustive treatment of all UK environmental SLAPPs, not least because of the difficulty of identifying them. Not all SLAPPs cases end up in court. The claimant's aims are often fulfilled without needing to take a case to court; the threat of such proceedings is often sufficient. Even where cases do end up in court, not all such cases are reported in the law reports. Where unreported cases are available in legal databases it will typically be difficult to assess which of the many, for example, injunction cases, may be SLAPPs. The examples discussed below were therefore sourced from secondary academic legal literature on protest and, from internet searches, for instances of UK SLAPPs where the term itself was used. To be included, a case had to be about the environment, though not necessarily exclusively so.

The UK cases help to demonstrate four key points. First, that there are some cases, not commonly identified as SLAPPs by existing UK commentary, which arguably belong in that category. The case law, in other words, helps to confirm our understanding of what a SLAPP is in a definitional sense. Second, that SLAPPs, although typically identified as a threat to social movement actors, can in some circumstances present a useful legal or other form of opportunity. Third, that not all reactive, protest-related civil litigation cases can be classified as SLAPPs, but that there are, nevertheless interesting examples of strategic use of these where creative defences are raised. Fourth, that resources are important when exploring whether SLAPPs affect protest; and they are also potentially important (alongside access and legal stock) in understanding whether relevant legal opportunities get the chance to be shaped in SLAPPs cases.

\section{Additional SLAPPs Cases}

First then, existing commentary doesn't always label cases as SLAPPs that arguably should attract that classification. Two such examples are the Heathrow Airport $v$ Garman ${ }^{2}$ and the Radley Lakes ${ }^{3}$ injunction cases. Both of these involved claimants seeking injunctions under the Protection from Harassment Act 1997 (originally designed to combat stalkers but later applied to protestors), against trespass and, in Garman, also nuisance and pursuant to byelaws. In Garman, Heathrow Airport was seeking to prevent 
protestors from disrupting operations at the airport during the Climate Camp taking place nearby. Radley Lakes involved protest against npower's plan to tip fly ash from its coal-fired power station at Didcot in former gravel pits that had become lakes of ecological significance and a valued local amenity. Both injunctions as originally sought were extremely broad (Liberty 2008), capturing within their scope many people beyond those who might reasonably pose any form of threat to the claimants' respective private interests. In the Heathrow case, the original form of the injunction would, for example, have potentially caught the many members of the National Trust. In Radley Lakes, the initial injunction granted was phrased, inter alia, to exclude the media from being present and taking photographs. ${ }^{4}$ However, neither case appears to have been described as an example of a SLAPP - probably because most UK commentary seems to reserve this term for cases involving intimidating damages claims against protestors. McLibel, Twyford Down, Monsanto v Tilly, BP and Greenpeace, and No Dash for Gas, which will be explored further below, all fit this latter mould. However, injunctions that are drawn unnecessarily broadly are also SLAPPs, because they seek to close down participation beyond what is necessary to protect the claimant's private interests.

\section{SLAPPs as Opportunity}

Second, and among my core arguments here, while SLAPPs are typically identified as legal threats, agency on the part of social movement actors is capable, in certain circumstances, of turning legal threat into a positive legal or other form of opportunity. This is conceptually distinct from counters to SLAPPs in the form of 'SLAPP-backs' suits, where defendants counter-sue claimants on legal grounds such as abuse of process, ${ }^{5}$ or using anti-SLAPP statutes, where legislative protection is specifically provided against SLAPPs (Sobczak 2008). The UK has no anti-SLAPP legislation and, thus far, only limited experience (discussed below) of SLAPP-backs. What we have principally seen instead is the creative use of defences in the original SLAPP claim itself, turning legal threat into legal opportunity, or, where this is not possible, the conversion of legal threat into media opportunity.

The McLibel case ${ }^{6}$ is perhaps the best known example of the creative use of legal defences. The case involved McDonald's suing two members of London Greenpeace (a group unconnected with Greenpeace International) for damages in defamation for allegedly libellous material about the corporation - including its environmental and health impacts - contained in leaflets they had been circulating. The case is widely regarded as a SLAPP because McDonald's aim was seen as one of silencing its critics via a heavy-handed claim for damages that they can never have expected to recover from the impecunious defendants. While McDonald's no doubt expected the two, who were not eligible for legal aid, to settle quietly and desist, ${ }^{7}$ the activists instead chose resolutely to defend the action, relying on truth and fair comment as defences 
to the tort of defamation. The availability of these defences in terms of legal stock was important, as was the unusual willingness of the protestors to sacrifice their earning potential ${ }^{8}$ to contest what became the longest running trial in UK history. However, as significant was their creative agency which saw the possibility of using the defences to convert legal threat into legal opportunity. This agency on the part of the protestors meant that the harmful practices that they were originally seeking to highlight received much more of an airing because of the significant international publicity that the case attracted. Although, in the end, McDonald's technically won on a number of points, the trial process overall was widely regarded as a victory for the protestors.

The case is also the only example found of a UK SLAPP-back. At the start of the trial, along with their defences, the defendants put forward a counter-claim in damages for libel in relation to documents distributed by McDonald's about the case in which the company had described the pair as liars who had knowingly made numerous false statements. ${ }^{9}$ While the judge held that the McDonald's statements were in the end defamatory (because some of the London Greenpeace statements had been found to be true), he dismissed the counter-claim on the grounds that the company was covered by the defence of qualified privilege. $^{10}$

The Monsanto v Tilly ${ }^{11}$ case saw anti-GMO protestors similarly using agency to test the bounds of legal stock in a civil injunction case. While the injunction itself may not have amounted to a SLAPP, it was combined with a large damages claim (considered further below) that puts the proceedings into SLAPPs territory. The case arose when members of GenetiX Snowball were involved in pulling up GM trial crops owned by Monsanto. In injunction proceedings, based on the tort of trespass, the protestors sought to rely on the established defence of necessity and, more novelly, a defence of justification in the public interest. The Court of Appeal rejected the necessity defence on the basis that it can only excuse trespass in cases where there is an immediate emergency and where no public authority is in a position to act. Here, the symbolic nature of the defendants' actions - in other words not pulling up all of the allegedly dangerous crop - meant that they could not assert a protective intent; in any event, the Department of the Environment existed to protect the public interest through the GMO licensing regime. More interesting for present purposes, the Court also rejected the very existence of a public interest defence in trespass. Its reason for doing so was one of justiciability, with the Court essentially unwilling to allow private law court proceedings to be used for political campaigning ends. According to Stuart-Smith $\sqcup$ :

The respondents are anxious to have a full trial at which they desire to call experts who will support the various dangers alleged to exist. If they do establish them, presumably on a balance of probability, then it is said their actions are justified. But a moment's reflection shows that the issue 
is incapable of being tried in a court with our adversarial system of justice ... The truth is in my judgment that the respondents wish to have the benefit of advancing their views in the forum of the court, with all its attendant publicity, not because it can amount to a defence, but because it is an admirable opportunity to proselytise their views. ${ }^{12}$

Thus although the defendants in Monsanto were not allowed in the end to marshall scientific expert witnesses, ${ }^{13}$ the case involved agency to try to turn a legal threat into an opportunity with their attempt to employ a tortious defence to continue their campaigning argument in court. On this occasion, they did manage to get at least some of that argument across. While the Court of Appeal's rejection of their attempt is likely to have closed future legal opportunity for creative trespass defences, the same cannot be said in relation to defamation, where truth and fair comment remain available defences.

While the McLlbel and Monsanto cases involved an attempt (successful in the former and, ultimately at least, unsuccessful in the latter) to turn the legal threat of a SLAPP into a legal opportunity, in other UK cases legal threats have been converted into media opportunities involving conventional and/or social media. Thus, post-Monsanto, the Garman defendants could not run the necessity or public interest defences to trespass and there was, it seems, little opening for similar arguments under the Protection from Harassment Act, byelaws or in nuisance. However, in media reports the legal threat was portrayed by a counsel for the defendants as an 'own-goal' in the sense that the injunction case had managed to provide significant media publicity for the Heathrow climate camp, which fell outside the scope of the injunction (Millward 2007). In this sense the legal threat became a conventional media opportunity. While one might query the degree of social movement agency involved in creating the media opportunity in this particular case (it was after all, described as an 'own' goal), such agency is clearly apparent in the No Dash for Gas West Burton case. There, climate activists scaled a gas fired power station chimney and stayed in place for a week, leading to a significant financial loss for the owners, EDF Energy. In response, EDF threatened to sue the protestors for five million pounds in damages (Monbiot 2013). However, this attempt at a damages SLAPP was met by a concerted movement social media campaign which gathered many thousands of signatures for an online petition, and the damages claim was soon dropped. Finchett-Maddock (2013) describes the online petition as a form of jury proxy, securing popular justice. EDF was no doubt concerned about customer boycotts - a realistic prospect for a large power company directly supplying individual consumers. ${ }^{14}$ In both Garman and No Dash for Gas therefore, the legal threat of the respective SLAPPs ended up in a media opportunity - conventional in Garman and social (and via clear agency) in No Dash for Gas. ${ }^{15}$ 
While we have seen above that not all SLAPPs cases involve the chance to attempt creative defences, it is worth noting that there are also non-SLAPPs reactive civil litigation cases which involve such strategic defences. These cases demonstrate that the judicialisation of environmental politics in civil cases is not necessarily confined to SLAPPs. Fillingham ${ }^{16}$ and Haughian ${ }^{17}$ provide good examples. They arose during the 1990s at the height of the anti-roads protests in the UK. In both, protestors were occupying land to be developed for road construction (the A34 Newbury bypass) and were subject to private law possession proceedings brought by the Department of Transport to recover the land. It is difficult to see such proceedings as SLAPPs because the government was protecting its private interests and its actions in doing so were not obviously disproportionate. The protestors put forward a defence in each case that remaining in possession of the land was justified because of a failure by the government to meet its obligations under EU law. In Fillingham, the defence was that staying on the land was needed to ensure that a rare snail would receive protection under the EU Habitats Directive. In Haughian, ${ }^{18}$ the argument was that the government compulsory purchase order was null and void because of a failure to conduct an environmental impact assessment required by EU law and therefore that the government had no greater right to the land. While both cases involved creative public law defences to private law claims, ${ }^{19}$ in neither was the court prepared to allow such defences, arguing that the appropriate place for such arguments was in public law proceedings via judicial review.

\section{The Role of Resources}

Resources are important in relation to SLAPPs in two key respects: first, in relation to their potential effect on protest; and secondly, for the impact they may have on the decision whether to respond strategically to SLAPPs by defending the litigation in court. With the first, SLAPPs are more likely to put individuals and groups with financial resources off further involvement in protest through fear of losing these resources. SLAPPs damages claims as a form of legal remedy are also likely to put off similarly situated others who are yet to get involved in protest but have been considering it: in other words, SLAPPs may have both a specific and a general deterrent effect. The 1990s anti-roads Twyford Down protest saw both injunctions and damages claims brought by the Department of Transport (DoT). The granting of an injunction against Friends of the Earth (FoE) protestors was said to have forced FoE to withdraw from further protest on the road site through fear of liability for fines on breaching the injunction and the effect this would have had on its wider campaigning ability (Fairlie 1993). However, the true (state) SLAPP element here was the $f 1.9$ million damages claim brought by the DoT against 76 of the protestors to cover the financial costs of the 
unlawful protests, including construction delays. This can be regarded as a SLAPP because the DoT must have known that it could not have hoped to recover such a sum from the mainly young and asset-less protestors; its true motivation would therefore seem to have been 'to discourage others from participating in similar actions' (Donson 2000: 148) - particularly the more asset rich middle class locals, many of whom also objected to the road's construction.

Twyford Down is not the only example of a UK SLAPPs damages claim. We have already seen that the No Dash for Gas case, discussed earlier, involved such a claim. Next, there is the protest which gave rise to the Monsanto injunction case above, which also saw a large SLAPPs damages claim that was eventually dropped (Donson 2000: 127, 131-132). And in 1997, on top of an injunction, BP sued Greenpeace and four of its campaigners for $£ 1.4$ million in damages for losses arising from Greenpeace interference with oil rig operations in the contested Atlantic Frontier (Donson 2000: 145). As a newspaper environment correspondent put it:

If the company had stopped at getting an injunction against further interference it would have won its point, gained sympathy and increased Greenpeace's woes. Its mistake was to threaten to bankrupt the organisation and its campaigners. This was one of the first attempts in Britain to import a tactic widely used in the United States, where it is called the ... Slapp ... BP's use of Slapp brought environmental groups that had criticised the Atlantic Frontier operation in behind Greenpeace and alienated public opinion (Lean 1997).

In part due, no doubt, to the negative publicity, the damages claim was soon dropped. As with the No Dash for Gas and Garman cases, the legal threat posed by the SLAPP in fact became a positive media opportunity for Greenpeace which, as Donson observes, is 'quite adept at using its own media links to challenge the reinvention of disputes [from an environmental dispute to a business disruption one] that these cases attempt to achieve' (Donson 2000: 146). The damages case and the David and Goliath publicity it attracted undoubtedly helped Greenpeace to fire up a climate-based campaign against new oilfields that, until that point, had been struggling (Lean 1997). That said, even for such a large and well-resourced organisation like Greenpeace, a sizeable SLAPPs damages claim like this can prove extremely disruptive, with its assets frozen at one stage and its continued existence threatened (Donson 2000: 145-146). Whether Greenpeace was put off further current protest in this specific case is difficult to determine as it is not really possible to distinguish between the effect of the injunction (which restrained such protest in any event) and that of the damages claim. Lean states that:

Although it agreed to abide by the legal order, this is normal practice (it wisely avoids fighting the courts), and it seems to have been withdrawing its campaigners from Foinaven anyway, partly on 
safety grounds. Having failed to land a knockout blow, BP dropped its damages suit without achieving its aim of forcing Greenpeace to agree not to take action against BP's other fields on the Frontier (Lean 1997).

This suggests that the damages claim did not work to put Greenpeace off future protest against BP's other fields. Its failure to do so may mean we need to be careful with any assertion that SLAPPs damages claims will automatically always put well-resourced groups or individuals off future protest. Although this is likely to be true of individual home owners or those with savings, it is probably not as true of very well-resourced groups such as Greenpeace, who are also SLAPPs 'repeat players' (Galanter 1974).

There are also a number of other alleged SLAPPs damages claims such as Ranger Rover's $f 12$ million claim for financial loss caused by interference to its factory production by Greenpeace activists protesting about the CO2 emissions of gas-guzzling 4x4 vehicles (Mead 2010). Ryanair was also said to be contemplating a £2 million lawsuit against Plane Stupid protestors who had disrupted flights at Stansted airport in 2008 as part of a climate campaign against aviation (Mead 2010). Whether writs were ever served in these casesi.e. whether they ever proceeded beyond media reported threats - is hard to establish (Mead 2010: 388), although merely putting a threat out may be enough to produce the desired chilling effect on protest for those with assets to lose.

While the above considers the potential effect of resources on protest in SLAPPs cases, there is also the question of what effect resources have on the strategic use of SLAPPs litigation by defendants. Contrary to Vanhala's (2011) view that resources are less important in explaining the uptake of reactive as opposed to proactive litigation, my argument here is that resources may also be important in explaining the active strategic use of civil reactive litigation. While with protest above it was about too many resources potentially affecting protest, here the picture is more complex. In some cases, such as McLibel, for example, the defendants had very little in the way of financial resources ${ }^{20}$ and yet were prepared strategically to challenge the SLAPPs libel damages claim. However, in contrast, there are injunction cases such as Twyford Down and Radley Lakes where a lack of resources threatened the ability of the defendants to challenge the injunctions.

Thus in Twyford Down, the only way in which two of the people caught by the injunction - Maggie Lambert and David Plumstead - were able to challenge it on appeal ${ }^{21}$ was because a trade union and Liberty, respectively, stepped in to support the appeals (The Independent 1993). As John Denham MP said of the former, his constituent, in a Parliamentary debate: 
Only a handful of people have been able to challenge injunctions in court. In Maggie Lambert's case, the court costs were $£ 36,000$, which could only be met because a third party, her trade union, could afford to fund the action. ${ }^{22}$

Similarly, in Radley Lakes, Dr Peter Harbour, a retired nuclear physics lecturer and home owner, stated in a memorandum to a Parliamentary joint committee inquiry into protest and human rights:

By the time an application has been made to the High Court it is impossible for a person of average means to defend themselves because the financial risks are much too large. This is not acceptable. Someone of average means can be injuncted for a long time (in my own case almost two years to date) without a defence being mounted, and without an opportunity to clear their name. I believe that I could clear my name, but I am unwilling to accept the considerable financial risks, so I am unable to defend myself against the accusations made (Joint Committee on Human Rights 2009).

Npower applied for and was granted the initial inunction ex parte (i.e. without the other party present) and without notice, which meant, procedurally, that the matter had to return to court for a continuation hearing where the other party could be present. In that hearing, Dr Harbour and the majority of the other defendants were represented by Liberty with counsel acting pro bono. ${ }^{23}$ However, at this stage, as the judgment notes, the defendants had been 'unable to advance an effective and full response to the application for an injunction ${ }^{24}$ and the injunction was continued subject to certain modifications, pending a full trial. It is the risk of facing costs for the other side at this full trial to which Peter Harbour is principally adverting above and which is likely to deter most protestors with average resources from contesting injunctions via a trial or subsequent appeal. ${ }^{25}$ In contrast, another defendant, journalist Adrian Arbib, who was also injuncted (for taking photographs at Radley Lakes), was, it seems, able successfully to challenge the injunction in the High Court thanks to support from his trade union, the National Union of Journalists (NUJ) (Joint Committee on Human Rights 2009).

\section{Conclusion}

Perhaps not surprisingly, environmental SLAPPs in the UK have followed the various waves of environmental protest since the 1990s, including roads, GMOs and climate change. Many of them involve the latter: Garman, BP and Greenpeace, No Dash for Gas, and also the alleged Range Rover and Plane Stupid cases, are all climate change related. They are also reminders that climate change litigation is brought by emitting industries as well as by the environmental movement. 
What the UK environmental SLAPPs cases demonstrate is that while SLAPPs are typically presented as legal threats, environmental social movement actors have been capable of using agency to convert such threats into opportunities. Some of these opportunities have been legal. In McLibel, the relevant defences to defamation were used to considerable effect. In other cases such as Monsanto, political public interest defences were employed but the legal stock for future legal opportunities using trespass defences was effectively closed off by the court's judgment. Other opportunities - as in Garman, No Dash for Gas (and BP and Greenpeace) - have been media related, whether conventional or social. The case law also illustrates that, within legal opportunity theory, issues of access may on occasions be problematic in reactive civil litigation (e.g., where injunctions are ex parte and without notice), and that legal stock is strategically key (in terms of whether relevant defences are available that can be used strategically to get a political campaigning point across), albeit that agency in developing such stock is also important. Related theoretical explanations for legal mobilisation such as resources also turn out to be important. While criminal reactive litigation may be financially relatively costless (state legal aid will typically be available), civil reactive litigation presents a more complex picture (with legal aid generally unavailable). The examples of the Twyford Down and Radley Lakes injunctions certainly suggest that individuals will struggle to challenge injunctions in court without financial support from, for example, trades union or human rights organisations. However, in the McLibel case, in contrast, the defendants managed to mount a very effective strategic defence to a SLAPPs damages claim on a relatively modest budget. What the cases suggest is that those with few financial resources to lose (e.g. the McLibel Two) are more inclined to challenge SLAPPs than those of average means (e.g. Peter Harbour, Radley Lakes), who, without guaranteed external support, are likely to be deterred by the financial risks of litigation.

Given that unconventional gas and fracking look set to be the next site for a wave of environmental protest if commercialisation proceeds, it will be interesting to see the extent to which SLAPPs cases arise as a result, or whether industry will have learned the lesson that such cases often result in own goals and may be counter-productive. Initial indications are not entirely positive: there has already been one case where a company involved in underground coal gasification has threatened an environmental campaigner with a SLAPPs damages claim for malicious falsehood and/or defamation in relation to a critical report on the technique, the industry, the company and its directors (Edwards 2014, Mobbs 2014). However, it appears that the company, Five Quarter, did not in the end proceed beyond the threat stage; given the potential defences available here, it may be that the lessons of McLibel have been learned.

\section{References}


Andersen, E.A., 2005. Out of the closets and into the courts: legal opportunity structure and gay rights litigation. Ann Arbor, MI: University of Michigan Press.

Beder, S., 1995. SLAPPs - Strategic lawsuits against public participation: coming to a controversy near you. Current Affairs Bulletin, 72 (3), 22-29.

Donson, F., 2000. Legal intimidation. London: Free Association Books.

Donson, F., 2010. Libel cases and public debate - some reflections on whether Europe should be concerned about SLAPPs. RECIEL, 19 (1), 83-94.

Doherty, B. , and Hayes, G., 2013. Having your day in court: judicial opportunity and tactical choice in antiGMO campaigns in France and the United Kingdom. Comparative Political Studies, 47 (1), 3-29.

Dunkley, J., 1997. Legal gag on green protests. The Independent, 26 Aug.

Edwards, R., 2014. Coal-gas company accused of bullying environmental campaigner with legal gag. Sunday Herald, 24 May.

Fairlie, S., 1993. SLAPPs come to Britain. The Ecologist, 23 (5), 165.

Finchett-Maddock, L., 2013. Responding to the private regulation of dissent: climate change action, popular justice and the right to protest. Journal of Environmental Law, 25 (2), 293-304.

Galanter, M., 1974. Why the 'haves' come out ahead: speculations on the limits of legal change. Law \& Society Review, 9 (1), 95-160.

Gleason, J., 2003. Strategic lawsuits against public participation. In: S. Stec, ed. Handbook on access to justice under the Aarhus Convention. Szentendre: The Regional Environmental Center for Central and Eastern Europe, 59-60.

Harlow, C., and Rawlings, R., 1992. Pressure through law. Abingdon: Routledge.

Hilson, C., 2002. New social movements: the role of legal opportunity. Journal of European Public Policy, 9 (2), 238-255.

Hilson, C., 2012. UK climate change litigation: between hard and soft framing. In: S. Farrall, T. Ahmed, and D. French, eds. Criminological and legal consequences of climate change. Oxford: Hart Publishing, 47-61.

Hutchinson, A.C., and Petter, A., 1988. Private rights/public wrongs: the liberal lie of the Charter. University of Toronto Law Journal, 38 (3), 278-297. 
The Independent, 1993. Ruling on Twyford pair lifted on appeal. The Independent, 4 Dec.

Joint Committee on Human Rights, 2009. Demonstrating respect for rights? A human rights approach to policing protest, seventh report of session 2008-09.

Lean, G., 1997. Stormy ride for two unlikely friends. The Independent, 24 Aug.

Liberty, 2008. Liberty's response to the Joint Committee on Human Rights: 'Policing and Protest'. London: Liberty.

Local Government Chronicle, 1996. Judge dismisses Newbury protesters' arguments. Local Government Chronicle, 14 Feb.

Millward, D., 2007. Heathrow chaos fears despite protest ruling. The Telegraph, 6 Aug.

Mobbs, P., 2014. Coal gas company warns - stop campaigning or we will sue. The Ecologist, 18 May.

Monbiot, G., 2013. EDF's vengeful £5m No Dash for Gas lawsuit is corporate and PR suicide. The Guardian, 28 Feb.

Morag-Levine, N., 2003. Partners no more: relational transformation and the turn to litigation in two conservationist organizations. Law \& Society Review, 37 (2), 457-510.

Morton, F.L., and Knopff, R., 2000. The Charter revolution and the court party. Peterborough, ON Broadview Press.

Mullis, A., and Scott, A., 2009. Something rotten in the state of English libel law? A rejoinder to the clamour for reform of defamation. Communications Law, 14 (6), 173-183.

Pring, G.W., and Canan, P., 1996. SLAPPs: getting sued for speaking out. Philadelphia: Temple University Press.

Roderick, P., 1996. The Newbury bypass litigation: part 1. Judicial Review, 1 (4), 252-254.

Rowell, A., 1996. Green backlash: global subversion of the environmental movement. London: Routledge.

Rosenberg, G.N., 2008. The hollow hope: can courts bring about social change? 2nd ed. Chicago, IL: University of Chicago Press.

Sheldrick, B., 2014. Blocking public participation: the use of strategic litigation to silence political expression. Waterloo, ON: Wilfrid Laurier University Press. 
Sobczak, M.J., 2008. SLAPPed in Illinois: the scope and applicability of the Illinois Citizen Participation Act. Northern Illinois University Law Review, 28 (3), 559-592.

Vanhala, L., 2011. Making disability rights a reality? Disability rights activists and legal mobilization. New York: Cambridge University Press.

Vanhala, L., 2012. Legal opportunity structures and the paradox of legal mobilization by the environmental movement in the UK. Law \& Society Review, 46 (3), 523-556.

Wells, J.A., 1998. Exporting SLAPPs: international use of the U.S. 'SLAPP' to suppress dissent and critical speech. Temple International and Comparative Law Journal, 12 (2), 457-502.

Wilson, B.M., and Rodríguez-Cordero, J.C., 2006. Legal opportunity structures and social movements: the effects of institutional change on Costa Rican politics. Comparative Political Studies, 39 (3), 325-351.

\footnotetext{
${ }^{1}$ See also Rowell (1996), Mullis and Scott (2009) and Finchett-Maddock (2013). There has also been occasional, brief comment on UK SLAPPs by overseas academics (Beder 1995, Wells 1998). Short, non-academic comment (by e.g. practising lawyers, journalists and independent researchers/campaigners) also exists (Fairlie 1993, Dunkley 1997, Monbiot 2013, Mobbs 2014). 2 [2007] EWHC 1957 (QB).

${ }^{3}$ RWE Npower v Carrol [2007] EWHC 947 (QB).

${ }^{4}$ For the original injunction, see http://www.epuk.org/News/475/the-npower-injunction-in-full?pg=4 [Accessed 11 June 2015].

${ }^{5}$ Abuse of process is theoretically available in the UK as a response to SLAPPs (Mullis and Scott 2009); however, it is not a damages counter suit as such - merely a way of having the existing SLAPP proceedings struck out.

${ }^{6}$ Steel and Morris v United Kingdom (2005) 41 EHRR 22. Although a later ECHR challenge, this contains details of the unreported High Court and CA judgments.

${ }^{7}$ As a number of other London Greenpeace members did.

${ }^{8}$ One, David Morris was an unemployed former postal worker on income support and the other, Helen Steel, a former gardener and part-time bar worker.

${ }^{9}$ http://www.mcspotlight.org/case/pretrial/counterclaim.html [Accessed 11 June 2015].

${ }^{10} \mathrm{http}: / /$ www.mcspotlight.org/case/trial/verdict/summary.html\#p30 [Accessed 11 June 2015]. The McDonald's statements were made in response to material put out about the trial by the McLibel Support Campaign.

11 [2000] Env LR 313 (CA).

12 n 11, 323-324.

${ }^{13}$ Unlike in the criminal reactive litigation Kingsnorth case (Hilson 2012).

${ }_{14}$ Many customers had already switched suppliers in response (Monbiot 2013).

${ }^{15}$ For another example, see the BP and Greenpeace damages claim discussed later.

${ }^{16}$ Secretary of State for Transport v Fillingham [1997] Env LR 73.

${ }^{17}$ Secretary of State for Transport v Haughian [1997] 2 CMLR 497.

${ }^{18}$ For a third, unreported, EIA case like Haughian, see Goillon (Local Government Chronicle 1996, Roderick 1996).

${ }^{19}$ NB., regarding access, residents and several nature conservation organisations, including WWF and CPRE, sought (unsuccessfully) to intervene in the CA in Haughian (Roderick 1996).

${ }^{20}$ See $\mathrm{n} 8$. In addition, neither owned their own homes. They received limited pro bono legal advice from qualified lawyers and financial support from public donations to the McLibel Support Campaign (MSC) which helped to pay for e.g. witness airfares, and some court costs and administrative expenses (http://www.mcspotlight.org/case/trial/story.html [Accessed 11 June 2015], and the ECHR report, $n 6)$. However, they represented themselves in court and the $(£ 35,000)$ MSC funding would not have covered legal representation, nor the risk of a sizeable damages award or the costs built up by the other side over such a prolonged trial (said to be around $£ 10$ million).

${ }^{21}$ Department of Transport v Williams (CA) (1993) Times, 7 Dec.

${ }^{22}$ HC Deb (1994) 250 col. 1511-8.
} 
${ }^{23}$ Carrol (n 3) and http://www.saveradleylakes.org.uk/resources/documents/Press_Release_18_04_07.pdf [Accessed 11 June 2015].

24 Para 2.

${ }^{25}$ It is unlikely that Liberty would have been prepared to cover the significant costs of a full trial. 